\title{
PENGEMBANGAN USAHA BUDIDAYA LELE DI DESA DOPLANG, SAWIT, KABUPATEN BOYOLALI MELALUI PRODUKSI PAKAN IKAN BERUPA PELET SECARA MANDIRI DARI KOTORAN AYAM PETELUR
}

\author{
Guruh Sri Pamungkas*, Dian Kresnadipayana dan Tri Mulyowati \\ Fakultas Ilmu Kesehatan, Universitas Setia Budi Surakarta \\ ${ }^{*}$ Email : guruhsp77@gmail.com
}

\begin{abstract}
ABSTRAK
Untuk membantu menyelesaikan persoalan mahalnya pakan pelet buatan pabrik di Kelompok Budidaya Lele Desa Doplang, Sawit, Kabupaten Boyolali maka dilaksanakan kegiatan IbM dalam bentuk kegiatan pembimbingan, pendampingan dan pelatihan bagi mitra. Metode yang digunakan untuk pencapaian tujuan tersebut adalah suatu proses alih teknologi dan dilaksanakan melalui penyuluhan, demonstrasi, praktik, dan pendampingan yang berkesinambungan. Ipteks yang ditransfer dalam program ini meliputi perancangan sepaket mesin pencetak pelet, proses analisis proximat bahan baku dan kotoran ayam, proses pengeringan dan pembuatan tepung dari kotoran ayam, proses formulasi bahan baku, pembuatan pakan ikan lele berupa pelet, pengeringan pelet dan uji lapangan pada ternak, evaluasi dan monitoring. Hasil dari pengabdian IbM ini cukup signifikan terhadap penurunan biaya pakan dari yang selama ini seharga Rp. 9300,- per kg menjadi Rp. 6000,- dengan Protein Kasar (PK) masih diatas $27 \%$. Hasil budidaya masih bisa bersaing dengan pakan komersial (pabrikan) dengan FCR (Feed Comsumption Rate) yang kecil sehingga produktivitas dan efesiensi meningkat karena harga pakan yang diproduksi lebih murah sekitar 35\% dibanding harga pabrik. Keuntungan juga didapatkan bagi kelompok peternak ayam bisa memproduksi bahan pakan berupa kotoran ayam serbuk (konsentrat) dengan harga Rp. 400,- per kg sehingga meningkatkan nilai jual dari kotoran ayam petelur dari Rp. 7000,- per karung 50 kg menjadi Rp. 20.000 per karung 50 kg.
\end{abstract}

Kata Kunci: peternak lele, mesin pelet ikan, kotoran ayam petelur

\begin{abstract}
To help resolve the question of the expensive artificial catfish feed in Doplang Farming Group Sawit, Boyolali Regency then implemented the activities Ipteks Bagi Masyarakat already in the form of activity of coaching, mentoring and training for partners. The methods used for the achievement of these goals is a process of technology transfer and implemented through outreach, demonstration, practice, and ongoing mentoring. The technology are transferred under this program include the design of a package of printing press pellets, proximat analysis of chicken manure and raw materials, the process of drying and production offlour from the chicken manure, the process offormulation of raw materials, manufacture feed catfish in the form of pellets, Pellet drying and field test on catfish, evaluation and monitoring. The result of IbM's devotion is quite significantly to the decrease in the cost of feed which costs IDR 9300,-per kg to IDR 6000,-with Crude Protein (PK) is still above 27\%. Cultivation can still compete
\end{abstract}


with commercial feed (the manufacturer) with FCR (Feed Comsumption Rate) are small so that productivity and efficiency is increased because the price of feed is produced around 35\% cheaper than the price of the factory. Advantage also obtained for groups of chicken breeders can producefeed chicken manure in the form of powder (concentrate) at a price of $\mathrm{Rp} 400 \mathrm{per} \mathrm{kg}$, thus increasing the value of manure laying hens from Rp. 7000 per sack $50 \mathrm{~kg}$ to Rp. 20,000 per $50 \mathrm{~kg}$ sack.

Keyword : catfish farmers, , fish pellet machine, laying hens manure.

\section{PENDAHULUAN}

Sektor perikanan dan peternakan memiliki peranan yang utama dalam memenuhi kebutuhan protein masyarakat di Indonesia. Mayoritas kebutuhan protein/ daging disuplay oleh kedua sektor tersebut. Setiap tahun kebutuhan akan protein hewani ikan mengalami kenaikan yang signifikan seiring tingkat kesadaran masyarakat akan pentingnya protein dalam. Selain produksi dari hasil tangkapan, hasil produksi budidaya diharapkan mampu ditingkatkan untuk menunjang kebutuhan ikan sebagai sumber protein yang meningkat tersebut.

Salah satu jenis perikanan budidaya yang sedang menjadi idola masyarakat di Indonesia saat ini adalah lele. Banyak faktor yang menjadikan lele idola bagi masyarakat, diantaranya adalah harga yang terjangkau, kandungan gizi yang tinggi, mudah didapatkan dan image masakan lele yang sudah menjadi makanan modern. Bagi pembudidayapun tentunya faktor- faktor tersebut menjadikan semangat tersendiri dalam rangka pengembangan usaha budidaya. Selain itu adanya faktor dukungan pemerintah melalui Balai Besar Pembibitan berhasil menciptakan varietas baru lele yang memiliki banyak kelebihan diantaranya: relatif cepat panen, konversi pakan yang rendah, dan tahan penyakit.

Permintaan lele konsumsi di Jawa Tengah dan D.I. Yogyakarta sangat besar yaitu sebesar 14 ton/hari dan 18 ton / hari (ANTARA Jateng.com, 2016). Banyaknya permintaan lele karena berjamurnya warungwarung pecel lele di pinggir jalan dan restoran yang menjajakan menu lele dengan berbagai variasi jenis olahan. Selain itu faktor kenaikan harga daging menyebabkan lele menjadi alternatif pengganti daging sapi, kambing maupun ayam yang relatif lebih murah.

Kementerian Kelautan dan Perikanan (KKP) mengungkapkan, tingkat konsumsi ikan dalam negeri selalu naik, meski tidak terlalu besar. Berdasarkan data dari KKP, tingkat konsumsi ikan pada 2010 sampai 2012 rata-rata naik hingga 5,44 persen. Di mana, pada 2010 tingkat konsumsi ikan mencapai 30,48 kilogram (kg) per kapita per tahun, pada 2011 sebanyak $32,25 \mathrm{~kg}$ per kapita per tahun. "Sedangkan pada 2012, tingkat konsumsi ikan mencapai 33,89 kg per kapita per tahun.

Tingkat konsumsi ikan belum merata setiap daerah, sehingga perlu terus memasyarakatkan Gemarikan (gerakan makan ikan)," katanya saat mengunjungi Tim Media Sindo di MNC Tower, Jakarta, Selasa, 26 Maret 2013. Sementara, tahun ini KKP menargetkan tingkat konsumsi ikan mencapai $35,14 \mathrm{~kg}$ per kapita per tahun. Untuk mencapai target tersebut, kementeriannya akan rajin berkampanye agar masyarakat gemar mengonsumsi ikan. Selain itu, KKP juga fokus pada industrialisasi kelautan dan perikanan dengan pendekatan ekonomi biru (blue economy). Menteri Kelautan dan Perikanan berharap, Indonesia tidak lagi impor ikan (Izzudin, 2013).

Dari sisi produksi, pada tahun 2011 produksi perikanan nasional mencapai 12,39 juta ton. Dari jumlah itu, produksi perikanan tangkap sebanyak 5,41 juta ton dan produksi perikanan budidaya 6,98 juta ton. Dari total produksi perikanan budidaya, jumlah budidaya ikan dalam kolam air tawar 
menyumbangkan angka hingga 1,1 juta ton. Sisanya adalah budidaya tambak air payau, budidaya di laut, budidaya dalam keramba dan budidaya jarring apung. Kenaikan produksi budidaya ikan dalam kolam air tawar pun cukup pesat yaitu berkisar 11\% setiap tahunnya.

Hal ini menujukkan adanya semangat yang tinggi di masyarakat untuk mengembangkan usaha budidaya ikan air tawar. Tentunya pertumbuhan produksi ini mengacu pada permintaan pasar yang terus meningkat. Produksi budidaya ikan air tawar dalam kolam didominasi oleh ikan mas, lele, patin, nila dan gurame. Lima jenis ikan tersebut menyumbang lebih dari 80 persen dari total produksi. Secara umum komersialisasi budidaya ikan air tawar dibagi dua segmen, yaitu pembibitan dan pembesaran. Budidaya pembibitan bertujuan untuk menghasilkan bibit bagi para peternak ikan. Sedangkan budidaya pembesaran bertujuan untuk menghasilkan ikan siap konsumsi (Alam tani, 2013, diakses dari http://www.alamtani. com/ikan-air-tawar.html).

Dalam kegiatan kali ini, pelaksana melibatkan dua kelompok mitra. Salah satu kelompok pembudidaya ikan lele di daerah Doplang, Teras kabupaten Boyolali adalah kelompok budidaya ikan lele Mina Usaha Tani (Kelompok Mitra I). Kelompok budidaya lele ini disahkan pada tanggal 8 Juni 2012 yang dituangkan dalam SK Kepala Desa No: 000/223/VI/2012 dengan anggota kelompok sebanyak 10 orang. Tahun 2014, kelompok budidaya tersebut mendapat pengukuhan sebagai Kelompok Pembudidaya Ikan (Pokdakan) kelas MADYA dan bahkan ketua Pokdakan Mina Usaha Tani yaitu Bapak Sidik Pramono dikukuhkan sebagai Penyuluh Perikanan Swadaya yang ditetapkan oleh Bupati Boyolali.

Tiap anggota kelompok memiliki beberapa kolam pembesaran lele dengan ukuran kolam $7 \mathrm{~m}$ x $10 \mathrm{~m}$ dengan jumlah bibit yang ditebar sebanyak 14.000 bibit lele ukuran $4-5 \mathrm{~cm}$. Proses budidaya pembesaran dilakukan selama \pm 3 bulan. Menurut Pak
Sidik Pramono selaku ketua kelompok budidaya, setiap hari beliau bisa panen 1 ton lele konsumsi (1 kg berisi 11-12 ekor lele), seperti juga dilansir dalam trobos.com dan kkp.go.id,

Dengan harga lele saat ini Rp.17.500,dan panen sebesar 1 ton per hari maka kolam tersebut mampu menghasilkan Rp. 17.500.000,- per hari, dan apabila dikalikan 30 hari (1 bulan) maka akan menghasilkan Rp. 525.000.000,- untuk satu orang saja. Angka tersebut belum sebagai keuntungan bersih karena masih dipotong biaya produksi. Saat ini untuk total panen yang dihasilkan Pokdakan Mina Usaha Tani per harinya bisa mencapai 5-7 ton yang 100\% terserap olah pasar dan tentunya merupakan suatu potensi usaha yang sangat menjanjikan.

Pokdakan Mina Usaha Tani memiliki koordinasi yang baik dalam mengembangkan dan memajukan anggotanya. Hal ini dibuktikan dengan dikukuhkannya menjadi Pokdakan tingkat Madya. Koordinasi yang baik tersebut juga sangat membantu anggota dalam pemenuhan kebutuhan produksi misal, peralatan, pakan, probiotik dan pelatihan- pelatihan yang diadakan oleh instansi pemerintah maupun swasta terkait dengan manajemen pemeliharaan, tata kelola keuangan dan strategi pemasaran. Bantuan dari Dinas Perikanan juga pernah didapatkan yaitu berupa bantuan, kolam fiber dan pakan. Pakan yang diberikan oleh dinas juga masih hasil produksi pabrik pakan yang sudah terstandarisasi kandungan nutrisinya. Pakan adalah segala sesuatu yang dapat dimakan, disenangi, dapat dicerna sebagian atau seluruhnya, dapat diabsorbsi dan bermanfaat bagi ternak. Oleh sebab itu pakan harus memenuhi semua persyaratan tersebut (Kamal, 1994). Sekitar $80 \%$ pengeluaran pada usaha budidaya adalah pada pakan, jadi apabila bisa menekan harga pakan maka, keuntungan pembudidaya ikan juga akan meningkat.

Kelompok Ternak Ayam Petelur Mulya Jaya (Kelompok Mitra II) merupakan kelompok peternak ayam petelur yang 
berlokasi juga di Desa Doplang. Kelompok ternak ayam ini disahkan dengan SK Kepala Desa Doplang No:000/120/IV/2016. Adapun jumlah anggotanya hanya 5 peternak karena didaerah ini mayoritas penduduknya adalah beternak lele. Tujuan dari dibentuknya kelompok peternak ayam ini adalah untuk memudahkan koordinasi dalam informasi terkait harga pakan, harga ayam/telur maupun penyediaan sarana dan prasarana produksi.

Meskipun baru disahkan tahun 2016 tetapi keberadaan anggota kelompok tersebut sudah ada beberapa tahun sebelum terbentuk. Populasi ayam untuk tiap-tiap anggota kelompok berbeda, ada yang memiliki populasi 2000, 3000 maupun sampai 5000 ekor. Harga ayam potong per ekor saat ini sekitar Rp. 27.000,- dan akan meningkat menjelang lebaran. Sedangkan untuk komoditas telur juga mengalami peningkatan biasanya menjelang lebaran. Saat ini harga telur per kg adalah Rp. 22.000,- dan akan mengalami kenaikan yng signifikan lebaran nanti.

Peternak ayam potong biasanya memelihara ayam mulai dari DOC (Day Old Chick) sampai siap panen sekitar 35 hari dengan bobot $1 \mathrm{~kg}-1,2 \mathrm{~kg}$ dengan harga per kg hidup sekitar Rp.17.000,- . Jadi apabila seorang peternak mempunyai populasi ayam 3000 maka pendapatan yang didapat saat panen adalah sekitar Rp. 61.000.000,. Dikurangi dengan biaya produksi ( pakan, vitamin dan obat-obatan) maka didapatkan keuntungan bersih peternak, yaitu biasanya Rp. 1500,- sampai Rp. 2500,- per ekornya. Agak berbeda dengan peternak ayam potong maka ayam petelur mengandalkan hasil berupa telur. Seorang anggota kelompok memiliki ayam petelur dengan populasi 5000 ekor dan produktifitas telur sekitar $80 \%$ maka akan dihasilkan telur sebanyak 4000 butir telur per hari atau $330 \mathrm{~kg}$ telur (asumsi $1 \mathrm{~kg}$ berisi 12 butir telur). Maka hasil yang didapatkan per harinya adalah sebesar Rp. 7.260.000,- dikurangi pakan dan kebutuhan produksi yang lain sebesar Rp. 7.260.000,dikurangi pakan dan kebutuhan produksi yang lain.
Berdasarkan identifikasi dari pelaksana dan mitra, maka permasalahan yang dihadapi adalah sebagai berikut :

1. Ketergantungan peternak lele konvensional terhadap pakan pellet pabrik secara umum masih sangat tinggi, sehingga dengan makin mahalnya harga pakan pellet pabrik membuat hasil pendapatan peternak semakin terkurangi bahkan hingga merugi.

2. Belum dipahami dan dikuasainya ketrampilan pembuatan pakan lele organik yang bersumber dari bahanbahan yang melimpah di sekitarnya, seperti kotoran sapi, ayam, puyuh, dll yang dapat diramu dengan bahan organik lainnya menjadi pakan lele organik yang cukup berkualitas.

3. Teknologi budidaya lele organik belum dipahami dan dikuasai oleh mitra IbM peternak lele, sehingga perlu disosialisasikan dan dikembangkan bersama-sama.

Salah satu faktor yang mempengaruhi pertumbuhan ikan lele sangkuriang adalah kualitas air, selain kebutuhan oksigen, NH3 juga merupakan faktor penghambat dalam pertumbuhan ikan. Pada tingkat konsentrasi $0,18 \mathrm{mg} / \mathrm{l}$ dapat menghambat pertumbuhan ikan (Wedemeyer, 1996).Kondisi alam yang mendukung tentunya perlu diimbangi dengan teknologi budidaya yang baik. Bagian yang perlu menjadi perhatian adalah pakan, dimana pakan merupakan pengeluaran terbesar dalam suatu usaha peternakan. Persentase $80 \%$ pengeluaran adalah untuk pembelian pakan. Pakan yang diberikan kepada ternak lele harus mencukupi kebutuhan nutrisi lele. Kualitas pakan yang digunakan sangat mempengaruhi pertumbuhan benih lele, hal ini berhubungan dengan kebutuhan nutrisi ikan lele yang meliputi protein, karbohidrat, lemak, serat, vitamin dan mineral.

Protein merupakan komponen pertama untuk pertumbuhan ikan yaitu sebagai sumber energi dan untuk perbaikan jaringan tubuh yang rusak. Mudjiman 1984 menyatakan 
bahwa protein sangat diperlukan oleh tubuh ikan baik untuk menghasilkan tenaga maupun untuk pertumbuhan. Pada umumnya ikan lele membutuhkan pakan dengan kandungan protein antara $28 \%-35 \%$. Rencana yang ideal dalam pengembangan perikanan dan budidaya ikan air tawar tersebut masih menghadapi kendala berupa masalah penanganan penyakit, masalah harga pakan pellet pabrik yang tinggi, cara pemasaran yang masih bergantung pada para tengkulak, serta perubahan cuaca yang ekstrim yang sangat berpengaruh terhadap tingkat produktifitas peternak. Tulisan ini untuk membantu peternak dalam memanfaatkan teknologi fermentasi untuk membuat pakan pellet ikan secara mandiri dan aplikasi teknologi tepat guna untuk memproduksinya.

Tabel 1. Perbandingan jumlah kotoran ayam pedaging dan petelur

\begin{tabular}{ccccc}
\hline Jumlah (ekor) & Jenis unggas & $\begin{array}{c}\text { Rataan bobot } \\
\text { badan (kg) }\end{array}$ & $\begin{array}{c}\text { Jumlah kotoran yg } \\
\text { dihasilkan (kg BK) }\end{array}$ & $\begin{array}{c}\text { Periode } \\
\text { (waktu) }\end{array}$ \\
\hline 100 & Ayam petelur & 2,0 & 1091 & 12 bulan \\
1000 & Ayam pedaging & 1,8 & 1227 & 9 minggu \\
\hline
\end{tabular}

Sumber : Ensminger (1992).

Apabila dibandingkan maka kotoran ayam petelur memiliki jumlah yang lebih banyak jika dibandingkan dengan ayam pedaging, hal ini tentunya berbanding lurus dengan jumlah produksi gas $\mathrm{CO}, \mathrm{NO}$, amonia and surfur oksida yang dihasilkan. Selain produksi gas yang sangat merugikan, Indonesia yang beriklim tropis merupakan lingkungan yang sangat potensial untuk perkembangan mikroorganisme, baik yang menguntungkan maupun yang merugikan sehingga dapat menyebabkan timbulnya berbagai penyakit yang menyerang ternak maupun manusia. Kotoran ayam merupakan bahan sisa yang bercampur dengan urin. Amonia yang dihasilkan oleh ayam, larut dalam air sehingga mudah diserap oleh partikel debu dan juga membran mukosa ( Indarsih, 2001). Gas ini bersifat toksik (beracun) terutama bagi otak. Selain menjadi sumber penyakit bagi ternak itu sendiri, limbah kotoran ayam juga menjadi pencemar udara yang bisa mengganggu pernafasan, jadi perlu ada pengelolaan limbah kotoran ayam tersebut agar tidak menjadi pencemaran lingkungan.

Kotoran ayam biasanya mengandung protein kasar $30 \%$ dengan kisaran antara 18$40 \%$ dan jumlah tersebut 37-45\%merupakan protein murni, 28- 55\% asam urat, 8- $15 \%$ amonia, 3-10\% urea dan nitrogen lainnya
(Muller, 1980). Kotoran ayam petelur sebagai limbah peternakan masih memiliki kandungan nutrien yang cukup baik, terutama kandungan proteinnya. Menurut Rasyaf (1994) bahwa kotoran ayam petelur merupakan sumber protein yang baik, karena masih terdapat bagian-bagian pakan yang terbuang melalui kotoran akibat tidak sempat dimanfaatkan dalam proses pencernaan. Masih menurut Rasyaf (1994), kotoran ayam masih mengandung nutrien yang berasal dari pakan tidak tercerna dan pakan yang tumpah. kotoran ayam petelur kering mengandung Protein Kasar 14,7 \%; Energi 1100 kkal/ $\mathrm{kg}$; Serat Kasar 16,2\%; Ca 7,5 \%; dan $\mathrm{P}$ $2,6 \%$. Kotoran ayam yang sudah kering dapat digunakan sampai level 30\% dari total pakan yang diberikan. Potensi kotoran untuk dijadikan bahan pakan sangat menjanjikan jika ditinjau dari kandungan nutrisi yang masih tinggi.

\section{TUJUAN DAN MANFAAT}

Setelah mendapatkan bimbingan, pelatihan dan pendampingan oleh Tim Pelaksana dengan melibatkan peran serta dari pakar dan tenaga ahli di bidang budidaya lele untuk kegiatan IbM peternak lele ini, maka diharapkan mitra mendapatkan manfaat berupa: 
Masalah ketergantungan terhadap pakan pellet pabrik semakin menurun, sehingga dapat menurunkan juga biaya produksi (pemeliharaan) ikan lele hingga mencapai harga dibawah harga pakan pabrik yaitu dibawah Rp. 9300,- per-Kg pakan.

Teknik budidaya lele organik yang dilatihkan dan dikembangkan, diharapkan memiliki banyak keunggulan, yaitu jangka waktu panen relatif singkat, hanya memerlukan waktu \pm 2 bulan, hasil produksi tinggi karena tingkat kanibal jauh lebih rendah, lebih tahan terhadap penyakit karena kualitas pakan, air dan lingkungan lebih terjaga dalam kondisi organik.

Pembuatan pellet ikan dari kotoran ayam, diharapkan dapat menekan biaya produksi pellet ikan lele, karena sebagian besar bahan bersumber dari bahan yang melimpah di sekitar peternak seperti kotoran ayam. Diperkirakan biaya produksi pellet ikan dari kotoran sapi hanya Rp 5.000,-/ $\mathrm{kg}$ dibandingkan harga pellet ikan pabrik sebesar Rp. 9.300,-/kg.

\section{METODE PELAKSANAAN}

Kegiatan IbM ini akan dilakukan dalam berbagai tahapan sebagai berikut:

a. Penyuluhan dan diskusi

Penyuluhan dan diskusi dilakukan diawal dengan tujuan untuk menjelaskan manfaat diadakannya program IbM ini. Kemudian dilanjutkan dengan edukasi bagi kelompok tentang bahan pakan, formulasi pakan, analisa pakan secara sederhana, penanganan limbah (dampak kotoran yang dibiarkan) dan pemanfaatan limbah kotoran sebagai bahan pakan ikan lele.

b. Pengadaan alat produksi

Penyediaan mesin/ peralatan yang digunakan dalam produksi pakan dan pengelolaan dengan cara pembelian seperti pellet mill, mixer dan pengering.

c. Pembuatan formulasi pakan dan produksi

Sebelum melakukan forming, bahan yang akan digunakan dipersiapkan dahulu. Kotoran ayam juga sudah diproses menjadi serbuk kering. Forming dilakukan dengan mengacu kebutuhan nutrisi ikan lele yaitu protein sekitar 33\% dengan tambahan parameter yang lain yaitu serat kasar, lemak kasar, metebolisme energi, serta mineral. Sesudah terformulasi maka langkah selanjutnya adalah dengan pencetakan pelet dengan mesin pencetak pelet dan pengeringan dengan oven. Hasil pakan yang sudah jadi diambil sebagian untuk uji proximat di laboratorium Peternakan Universitas Sebelas Maret.

d. Uji lapangan

Sebelum diaplikasikan pada semua kolam perlu diuji coba pada kolam uji coba untuk diamati. Parameter yang pakai adalah:

- palatabilitas pakan : kesukaan lele terhadap pakan

- Feed Consumption Rate (FCR): kemampuan pakan dalam mengasilkan daging lele.

e. Evaluasi terhadap hasil

Hasil panen pada kolam uji coba perlu dievaluasi dan di sesuaikan antara hasil analisa proximat dan FCR pakan.

\section{HASIL DAN PEMBAHASAN}

Kegiatan IbM yang sudah dilakukan adalah sebagai berikut:

a. Penyuluhan dan diskusi

1. Penyuluhan terkait sudah ada pencairan pendanaan program pengabdian masyarakat ini.

2. Penyuluhan tentang bahan pakan, formulasi pakan, analisa pakan secara sederhana, penanganan limbah dan pemanfaatan limbah kotoran sebagai bahan pakan ikan lele serta dilanjutkan dengan pelatihan formulasi pakan (dilaksanakan pada tanggal 24 Agustus 2017). 
b. Pengadaan alat produksi

Penyediaan mesin/ peralatan yang digunakan dalam produksi pakan dan pengelolaan dengan cara pembelian seperti pellet mill, mixer dan pengering.

c. Pembuatan formulasi pakan dan produksi

1. Sebelum melakukan forming, bahan yang akan digunakan dipersiapkan dahulu. Kotoran ayam juga sudah diproses menjadi serbuk kering.

2. Sesudah terformulasi maka langkah selanjutnya adalah dengan pencetakan pelet dengan mesin pencetak pelet dan pengeringan dengan mesin rotary drying.

3. Hasil pakan yang sudah jadi diambil sebagian untuk uji proximat di laboratorium Peternakan Universitas Gadjah Mada Yogyakarta.

d. Uji lapangan

Sebelum diaplikasikan pada semua kolam perlu diuji coba pada kolam uji coba untuk diamati. Parameter yang pakai adalah:

- Palatabilitas pakan : kesukaan lele terhadap pakan.

Setelah dilakukan ke ternak lele maka didapatkan kesimpulan bahwa pakan dari kotoran ayam yang dibuat memiliki palatabilitas yang baik, dibuktikan dengan tidak ada sisa pakan yang terdapat didasar kolam, semua pakan habis dimakan lele seperti pendapat Rasyaf (1994) bahwa kotoran ayam petelur merupakan sumber protein yang baik, karena masih terdapat bagian-bagian pakan yang terbuang melalui kotoran akibat tidak sempat dimanfaatkan dalam proses pencernaan.

- Feed Consumption Rate (FCR): kemampuan pakan dalam mengasilkan daging lele.

Pakan yang dihasilkan mencapai
FCR yang sama dengan pakan komersial yaitu rata-rata sekitar 1 .

e. Evaluasi terhadap hasil.

1. Hasil evaluasi didapatkan hasil bahwa pakan lele dari pengabdian IbM ini cukup signifikan terhadap penurunan biaya pakan dari yang selama ini seharga Rp. 9.300 per kg menjadi Rp. 6.000 dengan Protein Kasar (PK) masih diatas $27 \%$.

2. Hasil budidaya masih bisa bersaing dengan pakan komersial (pabrikan) dengan FCR (Feed Comsumption Rate) yang kecil sehingga produktivitas dan efesiensi meningkat karena harga pakan yang diproduksi lebih murah sekitar 35\% dibanding harga pabrik.

3. Keuntungan juga didapatkan bagi kelompok peternak ayam bisa memproduksi bahan pakan berupa kotoran ayam serbuk (konsentrat) dengan harga Rp. 400 per kg sehingga meningkatkan nilai jual dari kotoran ayam petelur dari Rp. 7000 per karung $50 \mathrm{~kg}$ menjadi Rp. 20.000 per karung $50 \mathrm{~kg}$.

\section{Kendala yang dihadapi:}

1. Kapasitas mesin yang masih terbatas sehingga produksi pakan belum bisa mencukupi kebutuhan seluruh anggota.

2. Ada beberapa peternak ayam anggota kelompok mitra yang vakum sehingga produksi kotoran menurun.

\section{KESIMPULAN DAN SARAN}

\section{Kesimpulan}

Dari seluruh proses pelaksanaan pengabdian masyarakat IbM ini dapat disimpulkan:

1. Hasil evaluasi didapatkan hasil bahwa pakan lele dari pengabdian IbM ini cukup signifikan terhadap penurunan biaya pakan dari yang selama ini seharga Rp. 9.300 per kg menjadi Rp. 6.000 dengan Protein Kasar (PK) masih diatas $27 \%$. 
2. Hasil budidaya masih bisa bersaing dengan pakan komersial (pabrikan) dengan FCR (Feed Comsumption Rate) yang kecil sehingga produktivitas dan efesiensi meningkat karena harga pakan yang diproduksi lebih murah sekitar $35 \%$ dibanding harga pabrik.

3. Keuntungan juga didapatkan bagi kelompok peternak ayam bisa memproduksi bahan pakan berupa kotoran ayam serbuk (konsentrat) dengan harga Rp. 400 per kg sehingga meningkatkan nilai jual dari kotoran ayam petelur dari Rp. 7000 per karung 50 kg menjadi Rp. 20.000 per karung 50 kg.

\section{Saran}

Adapun saran yang perlu diberikan untuk memaksimalkan hasil dari program ini adalah:
1. Perlu ada peran serta dinas peternakan dan perikanan yang bisa mengalokasikan anggaran untuk pemberian mesin pakan yang memiliki kapasitas lebih besar.

2. Perlu adanya pendampingan dari dinas terkait budidaya ayam petelur dan jaminan harga jual telur sehingga peternak ayam petelur tetap semangat berproduksi.

\section{UCAPAN TERIMAKASIH}

Ucapan terimakasih kami sampaikan kepada DP2M RISTEKDIKTI atas hibah Ipteks Bagi Masyarakat/ Program Kemitraan Masyarakat sehingga dapat dilaksanakan dengan baik dan bermanfaat bagi kedua mitra.

\section{DAFTAR PUSTAKA}

Food and Agricuture Organisation. 2008. FAOSTAT faostat.fao.org/site/569/default.aspx Accessed 3 March 2008

Ensminger, M. E. 1992. Poultry Science (Animal Agriculture Series). $3^{\text {rd }}$ Ed. Interstate Publisher, Inc. Danville. Illionis

Indarsih, B. 2001. Amonia dan Kesehatan Ayam. Ilmu Populer. Poultry Indonesia edisi November: $47-48$

Kamal, M., 1994. Nutrisi Ternak I. Gadjah Mada University Press. Yogyakarta.

Muller, Z. O. 1980. Feed From Animal Waste State of Knowledge. FAO, Animal Production and Health Paper Food and Agriculture Organization of United Nation Rome.

Rasyaf, M., 1994. Ayam Pedaging. Penebar Swadaya. Jakarta.

(http://www.trobos.com/detail-berita/2016/04/15/15/7367/potret-kampung-lele-boyolali)

(http://news.kkp.go.id/index.php/kampung-lele-boyolali-sentra-lele-di-jawa-tengah/). 